\title{
ŠIUOLAIKINĖS VISUOMENĖS ATSTOVO- KARININKO PROFESINĖS TAPATYBĖS AMBIVALENCIJOS BRUOŽŲ YPATUMAI
}

\author{
Doc. dr. Dileta Jatautaitė, Paulius Balsys \\ Generolo Jono Žemaičio Lietuvos karo akademija
}

\begin{abstract}
Anotacija. Straipsnyje analizuojami šiuolaikinès visuomenès atstovo - karininko profesinès tapatybès ambivalentiškumas, jo pasireiškimo bruožai ir ju ypatumai. Ambivalentiškos vertybès lemia vertybini konflikta karininko profesiniame identitete. Institucinès vertybès kyla iš kariuomenès, kaip specifines užduotis vykdančios organizacijos, todèl straipsnio autoriai, remdamiesi teorija ir empirika, išskiria pagrindinius Lietuvos kariuomenès karininko ambivalentiškumo bruožus per šiuolaikinès visuomenès vertybiniu poliu ịtaka karininko profesinei tapatybei. Straipsnyje taip pat atlikta Lietuvos ir užsienio autoriu vykdytu tyrimu ir teoriju analize. Tyrimo koncepcijoje tai grafiškai išdèstyta pagal tyrimo problema, tiksla ir uždavinius. Tyrimo tikslas - atskleisti karininko tapatybès vertybinio ambivalentiškumo bruožu ypatumus per šiuolaikinę karininko profesinę tapatybę, kuri pasireiškia dvejopumu, o problema yra analizuojama, kaip karininko tapatybę veikia du vertybiškai skirtingi poliai - institucija ir visuomene. Karininko profesinis identitetas turinio prasme susideda iš vertybiškai skirtingu orientyru, kai savo profesineje tapatybeje jis yra priverstas derinti kultūriškai skirtingus visuomenès ir kariuomenès vertybinius orientyrus.
\end{abstract}

Reikšminiai žodžiai: ambivalencija, savirealizacija, biurokratija, tapatybe்.

\section{Ivadas}

Ambivalentiškumo terminą XX amžiaus pradžioje pradejjo vartoti psichiatras E. Bleuler'is (2011). Vèliau R. Merton'as (1968) pateikè sociologinio ambivalentiškumo interpretaciją, kai ambivalentiškumas buvo ir yra suprantamas kaip rezultatas skirtingų socialinių vaidmenų, socialinės padėties, kuri prieštarauja individo kultūrinėms vertybėms ir neatitinka jo poreikių ir vertybių. Tada žmogaus elgesys darosi konfliktiškas dẻl kultūros ir civilizacijos diktuojamų elgesio ir gyvensenos normų ir jo negalëjimo laikytis šių normų. Po Antrojo pasaulinio karo Vakarų Europoje suintensyvëjus naujiems visuomenių kultūriniams-vertybiniams pokyčiams, ambivalentiškumas jau buvo asocijuojamas su liberalizacija, individualizmu ir hedonizmu. Toliau šie reiškiniai lemia vertybių kaitą visuomenėse ir darosi vis aktualesni - tradicijų reikšmė mažèja, individo įsipareigojimas grupinèms vertybėms nyksta, o jas keičia individo savirealizacija. Po karo ilgainiui įsivyravus 
taikos laikotarpiui moderniujų valstybių kariuomenių svarba sumenksta. Kariuomenèse vyksta organizaciniai pokyčiai ir jos iggyja civilinių organizacijų požymių. Postindustrinès visuomenès fone karininko tapatybè savo bruožais supanašèja su vadybininko ar iprastinio biurokratinio tarnautojo tapatybe.

Pavyzdžiui, Lietuvos prieškario laikais karininko profesija buvo siejama su heroizmu, idealu, garbe ir prestižu. Karininkų korpusas visada buvo priskiriamas kariuomenès elitui ir lyderiams, kurie vadovavosi aukštais kariuomenès etikos standartais. Šios vertybès ir dabar atsispindi ir tebèra aktualios Lietuvos kariuomenès norminiuose dokumentuose. Karininkas, būdamas kariuomenès atstovas, kartu yra ir šiuolaikinès visuomenès narys. Savo profesineje tapatybeje jis yra priverstas derinti kultūriškai skirtingus visuomenès ir kariuomenès vertybinius orientyrus. Todèl šiuolaikinès ambivalentiškos vertybès lemia karininko profesinio identiteto vertybinį konfliktą.

Problema - kaip kultūriškai skirtingų kariuomenès ir šiuolaikinès visuomenès vertybinių orientyrų ambivalencija veikia karininko profesinį identitetą?

Tikslas - atskleisti šiuolaikinès visuomenès karininko profesinès tapatybės ambivalencijos bruožus, pasireiškiančius vykstant kultūriškai skirtingų kariuomenès ir šiuolaikinès visuomenès normų sąveikai.

Tyrimo objektas - šiuolaikinès visuomenès atstovo - karininko profesinès tapatybès ambivalencijos bruožų raiška.

\section{Uždaviniai:}

1. Remiantis teorija ir empirika, įvardyti Lietuvos kariuomenès karininko tapatybès bruožus.

2. Atliekant tyrimą, atskleisti karininko tapatybès vertybinio ambivalentiškumo bruožų ypatumus.

3. Atlikti Lietuvos ir užsienio autorių vykdytų tyrimų ir teorijų analizę.

Tyrimo metodai: mokslinès literatūros ir atvirų šaltinių analizè, lyginamoji analizè, dokumentų analizè, analitinis, modeliavimo, apibendrinimo, sisteminis, dedukcinio pažinimo metodai, kokybinių ir kiekybinių duomenų analizè, pusiau struktūruotas interviu, fenomenologinè tyrimo strategija, atvejo tyrimo metodas ir aiškinamasis tyrimo problemos metodas.

\section{Esminiai ambivalencijos bruožų ypatumai, susiformavę karininko profesinèje tapatybẻje}

Po Antrojo pasaulinio karo Europoje ịsivyravo taika, ginkluoti konfliktai praktiškai išnyko. Situacijai aprimus, kariuomenès vaidmuo pamažu ėmė keisti savo pobūdį. Kariuomenei priskirti naujo tipo uždaviniai, tokie kaip taikos palaikymo (angl. peacekeeping) ir humanitarinès pagalbos (angl. humanitarian assistance) (Haltiner, 2006). Taikos sąlygomis kariuomenè tapo itin ịsprausta ị biurokratinius rèmus ir savo administravimu supanašejo su civilinėmis ir kitomis valdiškomis 
ìstaigomis (Manigart, 2006). Europos kariuomenių mastai mažèjo - nuo masinių kariuomenių pereita prie mažų, kompaktiškų, mobilių karinių organizacijų, kurios gali būti greitai ir paprastesnemmis procedūromis inkorporuotos ị daugianacionalines ir tarptautines pajègas.

Organizaciniai kariuomenių pokyčiai neretai yra suponuoti kultūrinių pokyčių, kurie veikia Vakarų Europos visuomenes. Prasideda vertybinè visuomeniu kaita, kuri tampa aktuali postmaterialistinèse visuomenėse. Vakarų Europoje prasidejjo kultūriniai ir vertybiniai pokyčiai, susiję su perèjimu iš industrinès visuomenès i postindustrinę. Normatyvinès sistemos vertybiné kaita visuomenèse darosi vis aktualesnè - tradicijų reikšmė mažeja, individo įsipareigojimas grupinèms vertybėms nyksta, ji keičia individo savirealizacija. Postindustrinèje visuomenėje individualizmas ir hedonizmas tampa pagrindinèmis vertybemis (Mannigart, 2006). Kolektyvines bendrojo gèrio vertybines nuostatas keičia individualistinė samprata ir asmeninis gèris. İsivyrauja bendrieji valstybingumo bruožai, būdingi postindustrinėms globalioms visuomenėms: mažèja patriotiškumo, nacionalumo samprata nebeturi tokios reikšmès, kokią turejjo industrinejje valstybëje. Karo sociologijos tyrimai rodo, kad racionalizacijos procesas, kuris sietinas su Vakarų visuomenėmis, neigiamai paveikè kariuomenes (Segal, 1983). Racionalizacijos bruožai, tokie kaip sekuliarizacija, biurokratizacija, lèmè, kad prasidejo tradicinių kariuomenès vertybių erozija. Autoriai teigia, kad kariuomenès vertybiniai lūkesčiai karininkams yra vis sunkiau pakeliami ir igyvendinami tarnyboje (Galigan, 1979).

Vertybiniai ir kultūriniai pokyčiai daro ịtaką ir Europos kariuomenèms. Anksčiau (laikotarpiu iki postindustrinès visuomenės) karininko profesija buvo siejama su herojiniu lyderiu, garbe, idealu. Karininkų korpusas buvo laikomas kariuomenės elitu, išsiskiriančiu savo lyderyste, aukštais kariuomenès etikos standartais. Tačiau postindustrinès visuomenès fone jis virsta vadybininku (Nuciari, 2006) ir iggauna eilinio biurokratinio darbuotojo pavidalą. Visuomenejje karininko statusas sumenko, palyginti su tuo, koks buvo visą laiką. Nuo seno iki dabar karininkai rengiami specialiose karinèse mokymo ịstaigose (pvz., akademijose). Tai etapas, kuriame pradedama formuoti jų vertybinè kariuomenès institucinè tapatybès struktūra. Vèliau karininkų profesinè tapatybė galutinai susiformuoja tarnaujant kariniuose daliniuose. Tačiau kartu kiekvienas karininkas yra ir šiuolaikinės visuomenès narys. Visuomenės, kurioje yra sąveikaujama vertybinėmis ir kultūrinèmis normomis, dažnai visiškai priešingomis kariuomenès vertybėms. Viso to padarinys - susidaro sąlygos karininko profesineje tapatybejje vertybinei ambivalencijai pasireikšti. Šiuolaikinèje visuomeneje karininkas patiria iššūkị, nes turi dvilypiškai prisitaikyti prie vertybiškai skirtingų kultūrinių kariuomenès ir šiuolaikinès visuomenès normų. 


\section{Karininko profesinès tapatybès vertybinio ambivalentiškumo tyrimo metodologija, eiga ir rezultatai}

2018 m. Lietuvos kariuomenès Daktaro Jono Basanavičiaus karo medicinos tarnybos psichologu atliktas tyrimas rodo, kad pagrindinè profesinès karo tarnybos karių sutarčių nutraukimo priežastis - karių nepasitenkinimas namų aplinkos, šeimos ir tarnybos suderinamumu, atlyginimu ir karjeros galimybemis. Statistika rodo, kad kiekvienais metais karinę sistemą anksčiau laiko palieka panašus nepasitenkinimą jaučiančių karininkų skaičius: 2015 m. 57 karininkai nutraukẻ sutartis pirma laiko (Generolo Jono Žemaičio Lietuvos karo akademiją baigè 51 kariūnas), 2016 m. - 46 (Karo akademiją baige 42 kariūnai), 2017 m. - 64 (Karo akademiją baige 53 kariūnai). Praktiškai kiekvienais metais panašus jaučiančių nepasitenkinimą tarnyba karininkų skaičius renkasi palikti krašto apsaugos sistemą.

Norint išsiaiškinti problemos priežastis, buvo organizuotas tyrimas, kurio tikslas - atskleisti karininko profesinès tapatybès vertybinį ambivalentiškumą ir jo bruožus. Ambivalencija, kaip teigia autoriai (Yair, 2007), pasireiškia kaip žmogaus patiriamo socialinio spaudimo, kuris kyla iš vertybių, normų konfliktiškumo, rezultatas. Empirinejje dalyje siekiama išryškinti karininko profesinės tapatybės bruožus, kurie bylotų apie dviejų skirtingų vertybinių orientyrų ịtampą karininko profesinėje tapatybeje. Institucinès ir visuomenès vertybès tam tikrais klausimais yra priešingos, todėl tyrime bus išryškinti profesinės tapatybès aspektai, kurie leidžia kalbèti apie karininko profesinę tapatybę ir skirtingų vertybių nesuderinamumą. Tai yra dviejų skirtingų vertybinių polių konfliktas karininko profesineje tapatybeje. Šio vertybinio konflikto išryškinimas turi atskleisti ne tik ambivalenciją, bet ir karininko problemas ir sunkumus, derinant šias vertybes savo kasdienybejje.

Šio tyrimo koncepcija yra perteikiama grafiškai (1 pav.). Koncepcijos bruožai atsispindi vienodai teorineje ir empirineje tyrimo dalyse. Teorinejje dalyje analizuojamos skirtingos vertybės (visuomenès ir institucijos) ir jų tapsmas. Empirineje dalyje įrodoma, kad karininkai disponuoja šiomis skirtingomis vertybèmis. Empirineje dalyje ịvyksta tyrimo kulminacija. Joje pasiekiamas tyrimo tikslas ir nustatoma, kaip šių vertybių konfliktiškumas sukelia ambivalenciją. 


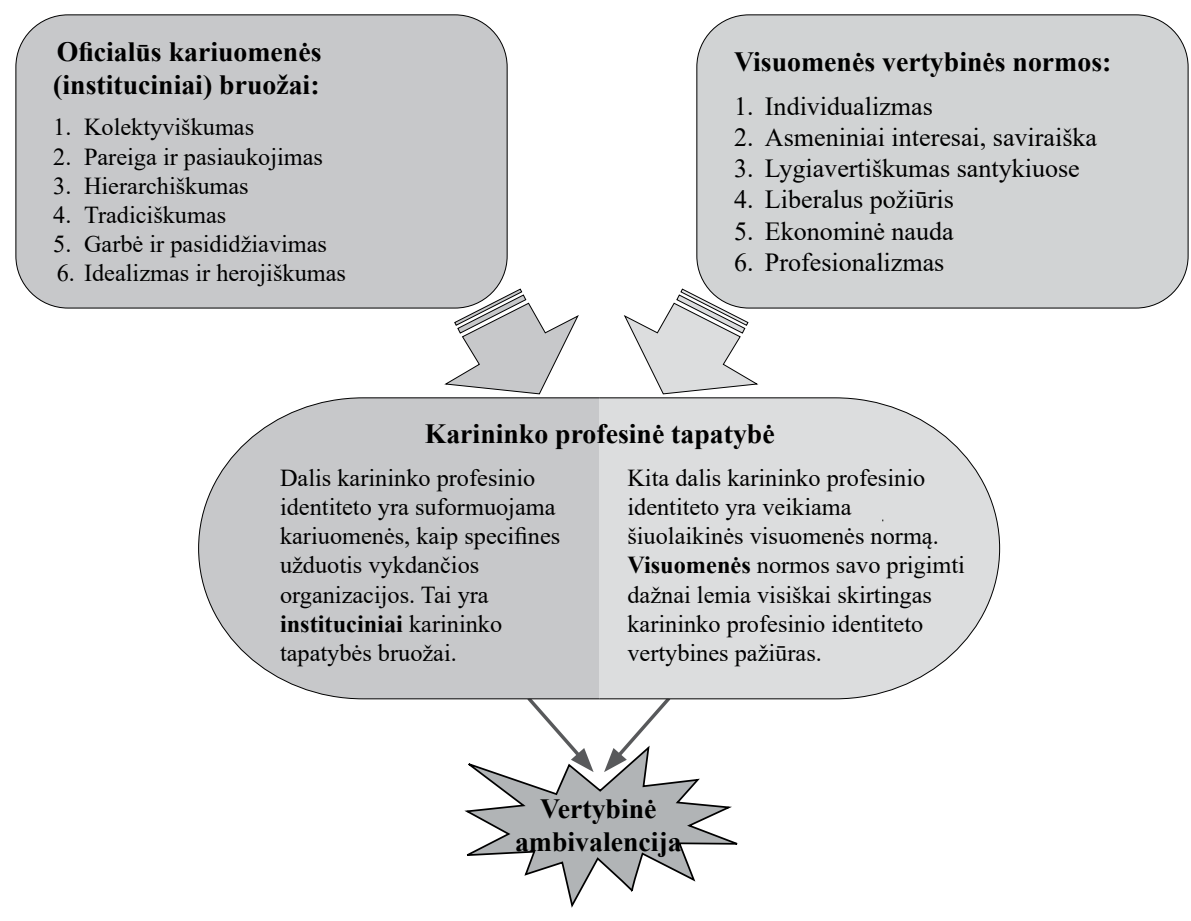

1 pav. Tyrimo koncepcija

Karininko profesinis identitetas turinio prasme apima vertybiškai skirtingus orientyrus. Institucinès vertybès, apie kurias kalba Charles'as Moskos'as (Moskos, paimta iš Caforio 2006), kyla iš kariuomenès, kaip specifines užduotis vykdančios organizacijos. Šios vertybès nusakomos kolektyviškumu, pareiga ir pasiaukojimu, hierarchiškumu, tradiciškumu, garbe ir pasididžiavimu, idealizmu ir herojiškumu. Šis kariuomenès vertybiškumas formuoja karininko profesinę tapatybę, kuri yra institucinè. Oficialios vertybès yra įprasmintos kariuomenès statutuose ir norminiuose dokumentuose (Karo tarnybos statutas, 2008).

Kitą karininko profesinès tapatybès dalị sudaro visuomenès vertybès (individualizmas, saviraiška, santykių lygiavertiškumas, ekonominè nauda, profesionalizmas). Šios vertybès kyla iš šiuolaikinès visuomenès (Roales, Segura 2010) ir nuo institucinių ne tik skiriasi savo turiniu, bet ir yra visiškai joms priešingos. Kaip teigia Moskos'as, šių vertybių skirtingumas kelia įtampą karininko profesinei tapatybėje (Moskos, paimta iš Caforio 2006). Tai leidžia išryškinti problemą: kaip šios savo reikšme priešingos vertybès gali derèti karininko profesinejje tapatybeje? Tiriant karininkų profesinę tapatybę buvo taikytas kokybinis tyrimo metodas, naudojant pusiau struktūruotą interviu. Pusiau struktūruotas interviu turinio atžvilgiu leido išgauti iš visų respondentų gana panašią empirinę informaciją. Kita vertus, bet kurio interviu metu respondentų atsakymai buvo laisvai pakreipiami tyrimo tematiką atitinkančia kryptimi arba siekiant tam tikrais klausimais įsigilinti, sužinoti daugiau reikalingų detalių. Tyrimui pasirinkta fenomenologine strategija: interviu 
metu siekta išsiaiškinti profesinę, socialinę karininkų tarnybos patirtị. Respondentai dažnai buvo skatinami analizuoti, gilintis ị ịvairias situacijas, kuriose atsispindètų jų požiūris ị tarnybą.

Tyrimui pasirinktas metodas - atvejo studija, siekiant išsiaiškinti fenomenalią organizacijos (kariuomenès) kultūrinę terpę ir jos įtaką individų profesinei tapatybei. Konkretūs tyrimo atvejai iliustruoja vertybių ambivalentiškumo problematiką. Atvejo studijos naudotos kaip aiškinamasis tyrimo problemos metodas, siekiant nuodugniai išnagrinèti ir suprasti tapatybės problematiką, suvokti svarbius veiksnius. Empirinèje dalyje duomenys interpretuojami, siejant teorines autorių įžvalgas su interviu metu gautais duomenimis. Šis metodas leidžia fenomenalią tyrimo problemą tirti teoriškai, analizuojant ir interpretuojant aktualius problemos aspektus.

Empiriniai duomenys buvo analizuojami pasitelkus turinio analizès metodą, interviu tekstai suskirstyti pagal pagrindines kategorijas, subkategorijas ir kodus. Empirika turinio atžvilgiu buvo suskaidyta i 3 pagrindines kategorijas: institucinių vertybių, visuomenès vertybių ir ambivalentiškų vertybių. Kategorizavimo schema nebuvo planuota iš anksto. Empiriniai duomenys suskirstyti pagal kategorijas atsižvelgiant $\mathfrak{i}$ interviu turinį. Planuojamas empirinių duomenų turinys buvo pakoreguotas konstruojant tyrimo interviu gaires. Interviu duomenys buvo rinkti 2018-11-2019-02. Interviu ịprastai trukdavo nuo 40 iki $60 \mathrm{~min}$. Tyrimo metu buvo paimta interviu iš 10 karininkų, baigusių Generolo Jono Žemaičio Lietuvos karo akademiją. Tyrimo medžiaga buvo renkama karininkų tarnybos vietoje, tarnybos metu jiems dèvint uniformas (uniformos dèvejjimas karininkams yra svarbus aspektas). Interviu buvo ịrašyti ị diktofoną. Visi karininkai yra ištarnavę mažiausiai 10 metų ir turi kapitono arba majoro karinị laipsnị ( 8 kapitonai ir 2 majorai). Iš 10 karininkų 9 buvo vedę ir turèjo šeimas. Tyrimo metu paaiškejjo, kad tai yra svarbus veiksnys, susijęs su viena iš ambivalencijų. Dèl tyrimo etikos sumetimų karininkams buvo suteikti išgalvoti vardai, o tarnybos vietos nesukonkretintos.

Pasirinktas 10 metų tarnybos laikotarpio kriterijus tam, kad būtų galima ištirti visiškai susiformavusį karininko identitetą. Lietuvos karininkų karjeros kelias yra ganètinai standartinis. Iprastai karininkai, baigę Karo akademiją, pirmus penkerius metus tarnauja koviniuose daliniuose, vadovauja kariniams vienetams, vykdo ìvairias užduotis. Todèl tai yra specifinè tarnybos patirtis. Po to karininkas dažniausiai skiriamas tarnauti į štabus, mokymo centrus ir kitas, labiau administracines, tarnybos vietas. Todèl tai leidžia kalbèti apie kitokią patirtị. Visi tyrime dalyvavę karininkai tarnauja ịvairiose administracinèse pozicijose ir daugiausiai vykdo biurokratinio pobūdžio užduotis, tačiau turi ir vadovavimo koviniams padaliniams patirties, todèl jų patirtis yra visapusè. 10 metų tarnybos laikotarpio kriterijus leidžia aprépti teoriniame modelyje autorių apibūdintas karininkų tarnybos patirtis ir jų nulemtas profesinio identiteto vertybes.

Interviu metu galima išskirti karininkų tarnybos slaptumą, kaip specifini veiksnị, galimai darantị ịtaką empiriniams tyrimo duomenims. Specifika yra ta, kad dažniausiai karininkai disponuoja jautria, riboto naudojimo tarnybine informacija, 
todèl visada turi galvoti, kokią medžiagą pateikia viešai. Tyrimo metu buvo atvejis, kai respondentas jautriai reagavo ị diktofoną. Îprastai ši dilema būdavo išsprendžiama prieš interviu nuodugniai informuojant apie tyrimo etikos ir jų pačių saugumo išlaikymo garantijas. Taip pat pasitikejjimas buvo igyjamas dèl to, kad karininkai dažniausiai sutikdavo duoti interviu tarpininkaujant ir prieš tai derinant per bendrus tyrèjo ir respondento pažĭstamus. Daugeliu atvejų interviu pradžia būdavo gana formali, respondentams siekiant pažinti interviu kontekstą ir sužinoti, kokios informacijos iš jų tikimasi. Nepaisant šios specifikos, interviu buvo sẻkmingi, iš kiekvieno išgavus pakankamai tyrimo tematiką atitinkančios informacijos. Visi interviu surengti tyrejjui atvykus ị karininkų tarnybos vietą jiems patogiu laiku.

Interviu metu pastebèta, kad ne visais aspektais institucinès ir visuomenès vertybès karininko profesinèje tapatybėje yra suderinamos. Skirtingos vertybės profesinèje tapatybèje kuria ịtampą ir leidžia kalbèti apie ambivalenciją (Yair, 2007). Nustatyta, kad ambivalencija profesinèje tapatybëje reiškiasi kaip idealų nuosmukis (natūraliai nesiekiama vertybių, nustatytų Lietuvos kariuomenès vado gairèse, norminiuose dokumentuose), individualus nepasitenkinimas (kai lieka nepatenkintas karininkų saviraiškos ar savirealizacijos poreikis), taip pat nepasitenkinimas šeimos klausimu (netenkina tai, kad nukenčia laikas, liekantis po tarnybos šeimai), hierarchiškumo erozija (menksta hierarchiniai santykiai su pavaldiniais). Francis' as Galligan'as taikliai ịvardija ambivalencijos problemą. Šiuolaikiniai karininkai turi visiškai skirtingas vertybes - kultūrines, filosofines - ir ideologinį matymą (Galligan 1979). Jiems hierarchinè sistema, tradicinès kariuomenès (institucinès) vertybès kelia nemažai iššūkių.

Šiuolaikinès visuomenès vertybès, kaip ir naujoji moralè, pasižymi liberalumu, individualumu ir demokratiškumu (Marcuse 1972). Tai lemia, kad karo tarnyba pateikiama ne kaip pareiga šaliai, bet kaip patirtis (angl. experience), pavyzdžiui, raginimas jaunuoliams stoti $\mathfrak{i}$ Lietuvos karo akademiją. Karininkų interviu rodo, kad postmaterialios vertybès lemia karininkų savirealizacijos svarbą. Individo saviraiška institucinejje organizacijoje nebūtinai yra ịgyvendinama. Norminiuose kariuomenès dokumentuose ịprasminta pareiga atlikti skirtas užduotis atsižvelgiant $\mathfrak{i}$ tarnybos, bet ne ị individo poreikius (Krašto apsaugos sistemos organizavimo ir karo tarnybos įstatymas, 1998 m.). Todèl interviu atskleidžia konfliktą, kuris lemia vertybinę ambivalenciją, susijusią su savirealizacijos raiška. Apžvelgus du skirtingus vertybių kilmès šaltinius (institucijos ir visuomenės), ambivalencijos priežastys ir problema yra lengviau nustatomos. Pasak profesoriaus Gad'o Yair'o (2007), sociologijoje ambivalentiškumas pastebimas kaip rezultatas, identifikuojant socialinę įtampą, spaudimą, sukeltą prieštaringų vertybių, socialinių normų. Moskos'as teigia, kad toks perejimas nuo institucinių prie darbo vertybių gali lemti vertybinę individų itampą (Moskos, paimta iš Caforio 2006). Organizacijos individai gali patirti spaudimą dèl tapatybės vaidmenų nenuoseklumo, sukelto prieštaravimo tarp institucijos ir visuomenès skirtingo vertybių turinio (kolektyviškumas versus individualizmas, hierarchiškumas versus horizontalumas ir kt., savirealizacija versus 
issakymas ir pareiga).

Pakitusi kariuomenès organizacinė santvarka (biurokratiškumas) dažnai užgožia institucines vertybes ir joms prieštarauja. Šie pokyčiai atsispindi karininko profesinejje tapatybëje kaip idealų nuosmukio požymis. Idealų nuosmukis pasireiškia tuo, kad karininkai neišskiria karo tarnybos, karininko profesijos moralumo vertybiniu požiūriu iš kitų civilinių darbų. Karininkų atsiliepimai leidžia spręsti, kad pagrindinès to priežastys yra ne vien pakitusi visuomenès moralè, bet ir pakitusi pati organizacija. Taikos metu įsigalèję civiliniai darbo standartai, tempas, biurokratiškumas sukuria aplinką, kuri neleidžia galvoti apie aukštesnius idealus garbę, pasiaukojimą, pareigą. David'as Segal'as ši procesą, apèmusį visų pirma visuomenę ir po to kariuomenę, vadina racionalizacija (Segal, 1983). Racionalizacijos procesas lèmè tai, kad kariuomenè perèmé civilinius organizavimo principus ir tapo biurokratiška. Racionalizacija neigiamai paveikè ir tradicinius kario tapatybès bruožus - tradicinis kario noras kautis sumenko, idealistinès vertybės nebeturi vietos raiškai. Kariuomenès racionalizacija glaudžiai susijusi su idealų nuosmukiu. Tai procesas, kuris daro neigiamą įtaką tradicinèms, institucinèms karininko tapatybès vertybèms. Morris'as Janowitz'ius tvirtina, kad karininkas laviruoja tarp dvieju polių - vienoje pusejje herojinis lyderis, ịkūnijantis tradicines vertybes, kitoje pusèje - biurokratinis darbuotojas, ịspraustas ị visuomenès standartus (Janowitz, 1960). Administracinis darbas yra ta karininko profesinès tapatybès dalis, kuri lemia, kad tolstama nuo herojiškumo, kuriam biurokratizuotoje rutinoje paprasčiausiai nèra vietos. Empiriniai duomenys rodo, kad karininkai nebesureikšmina idealistinių vertybių, viena vertus, dèl postmaterialių vertybių, kita vertus, dèl pakitusio tarnybos organizavimo - biurokratizacijos.

Visuomenès racionalizacija, apie kurią kalba David'as Segal'as, susijusi su ekonominiais gyvenimo aspektais, lemia, kad individai savo vertybes, pasirinkimus konstruoja atsižvelgdami ị asmeninę naudą (Segal, 1983). Racionalizacija, kuri pasireiškia kaip individualistinis bruožas, yra apėmusi ir karininko profesinị identitetą. Tyrimo duomenys rodo, kad toks individualizmo aspektas gali pasireikšti kaip šeimos sureikšminimas, prioretiškumas tarnybos atžvilgiu. Šeimos sureikšminimas, santykis su šeima leidžia kalbėti apie karininko profesinès tapatybès bruožą, rodantị, kad karininkui daugeliu atvejų tai yra svarbiau negu kolektyvinè kariuomenès vertybe் - tarnyba šaliai. Mancur'as Olson'as savo tyrimais, paremtais ekonominiais skaičiavimais, parodo, kad grupé, organizacija ar kolektyvas pirmiausia turètų būti suvokiamas kaip racionalių individų sambūris (Czech, 2016), kur individui svarbi jo asmeninè, o ne kolektyvinè nauda. Tai yra momentas, kai kolektyviniu vertybių tapatybès, reikalaujančios asmeninio išsižadejjimo, virsta individualizmu profesinejje tapatybejje. Karininkui darosi svarbiau jo asmeninis gyvenimas ir individuali karjera. Postherojinè epocha, kai kariui darosi svetimos tradicinès institucijos vertybès, nederančios su postmaterialistiniu pasauliu, individualizmu, kylančiu iš visuomenès. Postmaterialiosios visuomenès bruožai persmelkė ir kariuomenès vertybes. Empiriniai duomenys rodo, kad vyksta karininkijos vertybinè kaita - pri- 
oritetu tampa ne tautos gèris, bet individualistinis, asmeninis gyvenimas ir su tuo susiję aspektai. Karininko profesinèje tapatybèje atsiranda ịtampa dẻl tarpusavyje nederančių vertybinių orientyrų - asmeninių ir institucijos.

Karininko profesinè tapatybė apima ambivalentiškas visuomenès ir kariuomenès vertybes. Tai - skirtingi orientyrai, kurie pasireiškia profesiniame identitete. Empirika rodo, kad šios savo prasme skirtingos vertybès negali būti vienodai svarbios ir užimti tos pačios vietos asmeninèje vertybių skalëje. Tyrimas rodo, kad šių vertybių susidūrimas išprovokuoja nusivylimą. Susidūrus institucinèms ir individualioms vertybėms, institucinès dažniausiai užleidžia vietą individualioms karininkų vertybėms. Ši empirikos vieta atskleidžia, kad institucinès vertybès, nors ir oficialios, nèra tokios reikšmingos profesinejje tapatybejje kaip individualistinès visuomenès.

\section{Išvados}

Tyrimas atskleidè šiuolaikinės visuomenės karininko profesinès tapatybės ambivalencijos bruožus, pasireiškiančius dẻl kultūriškai skirtingų šiuolaikinès visuomenès ir kariuomenès normų sąveikos.

1. Gauti empiriniai duomenys įrodo, kad karininko profesinė tapatybė yra ambivalentiška. Karininko profesinị identitetą sudaro vertybiškai skirtingi kariuomenès (institucijos) ir visuomenès bruožai. Teorijos ir empirikos sintezė atskleidé naujų atejusių tarnauti karininkų susiformavusị šiuolaikinès visuomenès vertybinị filosofinị požiūrị, kuriam būdingi postmaterialios visuomenès atstovo bruožai (Roales, Segura, 2010). Profesinès socializacijos teorija rodo, kaip karininkai priima organizacijos kultūrą ir perima institucines kariuomenès vertybes (Volti, 2012). Tokiu būdu suformuojama kita profesinès tapatybès ambivalencijos pusè - oficialioji institucinè.

2. Tyrimas taip pat atskleide profesinès tapatybès ambivalentiškumo bruožus (Yair, 2007), pasireiškiančius per konfliktiškumą ir įtampą. Jie sukuria skirtingus vertybinius visuomenès ir kariuomenès orientyrus, kurie išryškẻja vykstant skirtingų vertybių sąveikai per savirealizaciją, idealų nuosmukį, šeimą ir hierarchiškumo eroziją.

3. Tyrimas liudija, kad vertybių ambivalencijos priežastis ir kilmė dažniausiai yra susijusi su visuomenès vertybiškumo aspektais (nusivylimas dẻl saviraiškos slopinimo, idealų nuosmukis kasdienybejje, nepasitenkinimas šeimos ir tarnybos suderinamumu). Tokia ambivalencijos kilmé rodo, kad karininko profesinei tapatybei visuomenès vertybiškumas daugeliu atvejų yra reikšmingesnis, nei institucijos siūlomos vertybès. Hierarchiškumo erozija - vienintelis ambivalencijos aspektas, kuris kyla iš institucijos vertybiškumo (Segal, 1983, Galligan, 1979).

4. Vienas pagrindinių tyrimo uždavinių buvo atskleisti skirtingų vertybinių orientyrų nulemtus karininko profesinès tapatybès bruožus. Interviu metu išryškinta viena karininko profesinès tapatybès pusių - institucinès vertybės (Moskos, 
paimta iš Caforio 2006): patriotiškumas, kolektyviškumas, prestižas ir garbè būti karininku, pareiga ir pasiaukojimas.

5. Tyrimo metu atsiskleidè kita karininko profesinès tapatybės ambivalencijos pusé - visuomenès vertybès, t. y. visuomenès vertybių bendras, visus bruožus vienijantis orientyras - individualizmas (Moskos, 1983; Galligan, 1979) ir karininko profesinès tapatybės bruožai: kritiškumas ir savirealizacija, materializmas, karjerizmas, santykio su pavaldiniais horizontalumas.

6. Profesionalumas ir „civiliškumas“ atsiskleidè kaip atskiri profesinès tapatybès bruožai.

7. Tyrimas rodo, kad kariuomenès biurokratiškumas yra vienas labiausiai demotyvuojančių veiksnių.

8. Šio tyrimo rezultatai, kaip ir kitų Lietuvos mokslininkų (Aleknevičienė ir kt., 2015) atliktų tyrimų duomenys, rodo, kad profesinio identiteto bruožai, kylantys iš visuomenès vertybinių orientacijų, karininkui yra reikšmingi ir svarbesni nei instituciniai.

\section{Literatūra}

1. Ayres, D. B.,Clement, S. D.,(1978), A Leadership Model for Organizational Ethics, Indianapolis: U.S. Army Administration Center.

2. Albrow, M., (1970), Bureaucracy, Macmillan, New York.

3. Benner, J., (2012), From the Iron Cage to Eichmann: German Social Theory and the Critique of Rationalization, University of Washington.

4. Bleuler, E., (2011), International Encyclopedia of the Social Sciences. 1968. [Last cited on 7 June 2011]. http://Encyclopedia.com.

5. Boene B., (2006), The Military as a Tribe among Tribes - Postmodern Armed Forces and Civil-Military Relations? Handbook of the Sociology of Military, Italian Interuniversity Centre of Historical and Military Studies.

6. Bredow, W., (2006), The Order of Violence, Handbook of the Sociology of Military, Italian Interuniversity Centre of Historical and Military Studies.

7. Caforio, G., (2006), Handbook of the Sociology of the Military. Italian Interuniversity Centre of Historical and Military Studies.

8. Czech S., (2016), Mancur Olson's Collective Action Theory 50 Years Later. A View from the Institutionalist Perspective. University of Economics in Katowice.

9. Deininger, D., (1970), The Career Officer as Existential Hero, US Naval Institute Proceedings.

10. Dingwall, R., (2008), Essays on Professions, University of Nottingham, UK.

11. Dunwell, R. P., (1977), Erosion of an Ethic, U.S. Naval Institute Proceedings.

12. Fearon, D. J. (1999), What is identity (As we now use the word)? 
Department of Political Science, Stanford University.

13. Flammer, M. P., (1976), Conflicting Loyalties and the American Military Ethic, American Behavioral Scientist, May-June.

14. Foucault, M., (1998), Disciplinuoti ir bausti. Kalejjimo gimimas, Atviros Lietuvos fondas.

15. Galbraith, J. K., (1967), The New Industrial State, New York: New American Library.

16. Galligan, F. B., (1979), Military Professionalism and Ethics, Newport, Naval War College Press.

17. Goffman, E., (1961), Encounters, Indianapolis.

18. Huntington, S., (1957), The Soldier and the State, Cambridge: Belknap Inglehart R., (2000), Globalization and Postmodern Values, The Washington Quarterly.

19. Aleknevičienė, J. Pocienè, A. Vileikinè, E., (2015), Motyvacija tarnauti Lietuvos kariuomeneje, Vilnius: Generolo Jono Žemaičio Lietuvos karo akademija.

20. Janowitz, M., (1960), The Professional Soldier, Free Press.

21. Jatautaite, D., Kazimianec, J. (2018), The importance of sustaining secure ambience for cadets of the Military Academy of Lithuania via balancing emotions and perception in attaining accelerated second language learning and acquisition // Journal of Security and Sustainability Issues, Vilnius: Generolo Jono Žemaičio Lietuvos karo akademija. ISSN 2029-7017. eISSN 2029-7025. 2018, vol. 8, no. 2, p. 161-170. DOI: 10.9770/jssi.2018.8.2(4).

22. Jatautaite, D., Kazimianec, J., (2018), The second foreign language teaching at the Military Academy of Lithuania (on the basis of audiovisual method $)=$ Antrosios užsienio kalbos mokymas Generolo Jono Žemaičio Lietuvos karo akademijoje // Šiuolaikinès visuomenès ugdymo veiksniai $=$ The Factors of Education in Modern Society: scientific journal, Vilnius: Generolo Jono Žemaičio Lietuvos karo akademija. ISSN 2424-6131. eISSN 2424-614X. 2018, t. 3, p. 259 268. Prieiga per internetą: http://ka.lt/lt/mokslineveikla/leidiniai/siuolaikinesvisuomenes-ugdymo-veiksniai /download.html?id=1074;pdf_id=61818.

23. Kane, T., (2011), Why our best officers are leaving?, The Atlantic, January/February.

24. Kenneth, A., (1997), The Postmodern Self; A Theoretical Consideration, Quarterly Journal of Ideology, Vol. 20 p. 3-24.

25. Kerwin, W. T., (1978), Values of Today's Army, Soldiers.

26. King, E. L., (1972), The Death of the Army, A Pre-Mortem, New York: Saturday Review Press.

27. Kummel, G., (2006), A soldier is a soldier is a soldier?!, Handbook of the Sociology of Military, Italian Interuniversity Centre of Historical and Military Studies.

28. Lietuvos karinè doktrina, Lietuvos kariuomenè, $2016 \mathrm{~m}$.

29. Lietuvos kariuomenès vadas, (2012), Lietuvos kariuomenès vizija. 
30. Lindermann, T., Martin, L., (2006), The military and the use of force, Handbook of the Sociology of Military, Italian Interuniversity Centre of Historical and Military Studies.

31. Manigart, P., (2006), Restructuring of the Armed Forces, Handbook of the Sociology of Military, Italian Interuniversity Centre of Historical and Military Studies.

32. Marcuse, H., (1972), Counter-Revolution and Revolt, Beacon Press Boston.

33. Meade, H. J., (1977), Commitment to Integrity, Air University Review.

34. Merton, R., (1968), „Social Structure and Anomie“, Translation: in Merton, Robert. Social Theory and Social Structure. New York: Free Press: 185214.

35. Moskos, C., (1981), Institution versus Occupation: Contrasting Models of Military Organisation, Department of Sociology, Northwestern University.

36. Nuciari, M., (2006), Models and explanations for military organisation, Handbook of the Sociology of the Military, Italian Interuniversity Centre of Historical and Military Studies.

37. Roales, J., Segura, A., (2010), Intergenerational Differences in Materialism and Postmaterialism Values in a Spanish Sample, International Journal of Psychology and Psychological Therapy.

38. Rothman, R. A., (1987), Working: Sociological Perspectives, Englewood Cliffs, NJ: Prentice Hall.

39. Rukavishnikov, V., Pugh, M., (2006), Civil-military relations, Handbook of the Sociology of Military, Italian Interuniversity Centre of Historical and Military Studies.

40. Rukavishnikov, V., Pugh, M., (2006), Civil-military relations, Handbook of the Sociology of Military, Italian Interuniversity Centre of Historical and Military Studies.

41. Segal D., (1983), Change in military organization, JSTOR. 


\title{
PECULIARITIES OF MANIFESTATION \\ OF THE AMBIVALENCE TRAITS OF PROFESSIONAL IDENTITY OF AN OFFICER IN THE MODERN SOCIETY
}

\author{
Assoc. Prof. Dr. Dileta Jatautaitė, Paulius Balsys
}

General Jonas Žemaitis Military Academy of Lithuania

\begin{abstract}
Summary
The article analyzes the ambivalences of professional identity of an officer in the modern society and the features of its manifestation. Ambivalent values lead to a value conflict in the officer's professional identity. Institutional values stem from the military in how specific tasks are performed by organizations. Thus, based on the theory and empiricism, the authors of this article single out the ambivalence of an officer of the Lithuanian Armed Forces behind the principles of his/her professional identity chosen by the value poles of the modern society. The article analyzes the research and theory of the Lithuanian and foreign authors. The concept of the research is graphically presented in the problems and purpose of the work. The aim of the study is to reveal the features of ambivalence of a military person's identity through present officer's professional identity. The problem of the research is analyzed through the officer's professional identity that in terms of content consists of value orientations, when, in relation to the professional identity, an officer is forced to combine culturally essential values of the society and the military.
\end{abstract}

Keywords: ambivalence, self-realization, bureaucracy, identity. 


\section{AUTORIŲ LYDRAŠTIS}

Autoriaus vardas, pavardė: Dileta Jatautaite

Mokslo laipsnis ir vardas: socialinių mokslų daktarè, docentè

Darbo vieta ir pareigos: Generolo Jono Žemaičio Lietuvos karo akademijos Užsienio kalbų centras, docente

Autoriaus mokslinių interesų sritys: psicholingvistika, glotoedukologija, edukologija, tradiciniai ir netradiciniai kalbų mokymo metodai ir metodologija, psichoedukologiniai kalbų mokymo ir išmokimo pagrindai

Telefonas ir el. pašto adresas: 85210 3560; dileta.jatautaite@mil.lt

Autoriaus vardas, pavardė: Paulius Balsys

Mokslo laipsnis ir vardas: doktorantas, Lietuvos socialinių tyrimų centras

Darbo vieta ir pareigos: Generolo Jono Žemaičio Lietuvos karo akademija, Kariūnų batalionas, kuopos vadas

Autoriaus mokslinių interesų sritys: karo sociologija, bendroji sociologija

Telefonas ir el. pašto adresas: +370 67416 151; paulius.balsys@mil.lt

\section{AUTHORS' COVER LETTER}

Author's name and surname: Dileta Jatautaite

Academic degree and name: Associate Professor, Doctor

Workplace and position: General Jonas Žemaitis Military Academy of Lithuania, Centre of Foreign Languages, Associate Professor

Author's research interests: psycholinguistics, glotoeducology, traditional and non-traditional language teaching methods and methodology, psychoeducational basis in language learning and acquisition

Telephone and e-mail address: +370 5210 3560; dileta.jatautaite@mil.lt

Author's name and surname: Paulius Balsys

Academic degree and name: $\mathrm{PhD}$ student

Workplace and position: General Jonas Žemaitis Military Academy of Lithuania, Company Commander

Author's research interests: military sociology, general sociology

Telephone and e-mail address: +370674 16 151; paulius.balsys@mil.1t 